\title{
Effect of Interest Rate Regulation on the Relationship Between Loan Lending Policies and Financial Performance of Commercial Banks in Kenya
}

\author{
Hellenn Araka ${ }^{1} \mathrm{PhD}$ Candidate Dr. Simeyo Otieno ${ }^{2}$ Dr. Vitalis Mogwambo ${ }^{2}$ \\ 1.School of Business and Economics, Department of Finance and Accounting, Jaramogi Oginga Odinga \\ University of Science and Techonology (Teachers Service Commission P.o Box 673-40300 Hombay), Kenya \\ 2.Lecturer, School of Business and Economics, Department of Finance and Acoounting, Jaramogi Oginga \\ Odinga University of Science and Technology P.o Box 210-40601 Bondo, Kenya
}

\begin{abstract}
The first specific objective was to determine the relationship between credit risk management and financial performance of commercial banks in Kenya. The second specific objective was to determine the effect of interest rate regulation on the relationship between loan lending policies and financial performance of commercial banks in Kenya. The study used descriptive research design and the research philosophy used was positivism. The study adopted a census survey and purposive sampling method targeting 43 bank managers, 43 credit managers and 43 operations managers of the 43 commercial banks in Kenya for period 2013 to 2018. Document analysis guide was used to collect secondary quantitative data for period 2013 to 2018 from the commercial bank's financial reports and questionnaires were used to collect primary data. The questionnaires which were administered to the respondents were structured. Content validity was used to determine the validity of the instruments. Data was analyzed using multiple linear regression method. The findings of the study revealed that loan lending policies; credit risk management measured by (non-performing loans and debt collection costs) have a significant and negative impact on ROA of commercial banks in Kenya. The study findings revealed that there exists a relationship between interest rate regulation, loan lending policies and financial performance of commercial banks. The study recommended that commercial banks should strengthen its loan lending procedures, use the services of Credit Reference Bureau, train credit officers on how to scrutinize customers and give out loans which have collateral security only.
\end{abstract}

Keywords: Loan lending policies, interest rate regulation, credit risk, non-performing loans financial performance, commercial banks

DOI: $10.7176 / \mathrm{RJFA} / 12-4-05$

Publication date: February $28^{\text {th }} 2021$

\subsection{Introduction}

Lending by commercial banks has become a major function of the commercial banks because of its direct effect on the economic growth of a country, business development and financial performance of commercial banks. Bank lending is guided by loan lending policies which are guidelines and procedures put in place to ensure smooth lending operations. The lending function is considered as the most important function of any commercial bank since most of the bank's earnings are generated from interest income. Bank lending if not properly assessed, involves the risks that the bank shareholders may not realize any income, benefits such as return on assets, return on equity. Lending is a risky business in that repayment of the loan is not always guaranteed and most of the times depend on other factors not in the control of the borrower hence affecting return on assets. Banks are assumed to be risk averse. Therefore every commercial bank's interest is to look for different techniques that will reduce the overall credit risk as much as possible and still be able to get profit from lending businesses (Akoth 2106).

(Ngetich 2011) defines interest rate as money borrowers pay for the use of money they borrow from the lender or financial institutions as a fee on borrowed asset. (Fisher 1980), considered interest rate as the price of money or the percent of premium paid in money at the one date in terms of money to be on hand one date later. Therefore interest on loan portfolios is the price the lender charge the borrower for using the borrowed money. The Central bank sets interest rates with a view of stabilizing inflation at the target within a reasonable time usually 1 to 3 years.

The cap on interest rate in Nigeria adopted in 1994 was lifted in October 1996 and a flexible interest rate regime largely determined by the forces of demand and supply for funds was put in place and this has remained so since late 1990s to date. However, the problem has been that the market based approach to interest rate management in Nigeria has always been associated with substantial interest rate volatility. In 1986, Nigeria interest rate was as low as $2.5 \%$ and it rose to $8.9 \%$. Nigeria's interest rates fluctuated over time as the central bank was to regulate and supervise all authority introduced the indirect monetary instruments in order to control interest rate and the rate of inflation. The interest rate has doubled through the period of 1997 to 2007 attaining a peak of $24.62 \%$. The Central Bank of Nigeria holds it benchmark interest rate at $14 \%$ as at July 2016 making the economy 
to remain in recession. Interest rate in Nigeria averaged 10.28\% from 2007 to 2016 reaching 14\% in January 2017. The number of borrowers increased and commercial banks gave huge loans to the public. The financial performance of commercial banks in Nigeria in terms of profitability (ROA) increased by 10\% (Mkinde 2013).

(Munyiri 2010) stated that bank lending policies in lending institutions in Kenya is a statement of the philosophy, standards and guidelines that its employees must observe in granting or refusing a loan request. These policies determine which retail or corporate clients that commercial banks approve for loans and which will be avoided and control of the existing facilities as well as procedures on how to collect from delinquent loans.

\subsection{Resarch Objectives}

The general objective of the study was to determine the effect of interest rate regulation on the relationship between loan lending policies on financial performance of commercial banks in Kenya. Two specific objectives derived from the main objective of the study were as follows:

(i) To establish the relationship between credit risk management and financial performance of commercial banks in Kenya

(ii) To determine the effect of interest rate regulation on the relationship between loan lending policies and financial performance of commercial banks in Kenya

\subsection{Research Hypotheses}

(i) $\quad$ Ho1 $_{01}$ There is no significant relationship between credit risk managment and financial performance of commercial banks in Kenya.

(ii) Ho2: Interest rate regulation has no significant effect on the relationship between loan lending policies and financial performance of commercial banks in Kenya.

a. Interest rate regulation has no significant effect on the relationship between the credit risk managment and financial performance of commercial banks in Kenya.

\section{THEORIES AND MODELS OF LOAN LENDING POLICIES}

\subsection{Loan policies and procedures}

Loan policy is the main means by which banks provide guidance and focus to its lending activities of a banking institution. In addition to subscribing standards, loan policy also states that the bare minimum required for a bank's credit policy to ensure a structure of ensuring loan quality and profitability goals in such a way it conforms with the institutions policy goals. Loan policy sets principles for portfolio structure individual credit decisions, fair lending and compliance management. Loan policy is the chief main means by which banks provide guidance and the focus to its lending activities of the banking institutions (Akoth, 2016).

\subsection{Interest Rate Regulation}

(Nakayiza 2013) stated that interest rate is a rate which is charged or paid for the use of money. An interest rate is often expressed as an annual percentage of the principal. It is calculated by dividing the amount of interest by the amount of principal. In general, interest rates rise in times of inflation, greater demand of credit, tight money supply or due to higher reserve requirements for banks. A rise in interest rate for any reason tends to lessen business activity because credit and stock market becomes more expensive as investors can get better returns from bank deposits or newly issued bonds or loans than from buying shares.

Table 2.1 Effect of Interest rate regulations in Kenya

\begin{tabular}{lllccc}
\hline & Year & Loans Lent & NPLs & Growth in Credit & Profits \\
\hline \multirow{3}{*}{ Commercial } & 2013 & 3.50 tribillion & $8.7 \%$ & $18.4 \%$ & $16-20 \%$ \\
Banks & 2014 & 3.20 tribillion & $5.6 \%$ & $17.7 \%$ & $15-20 \%$ \\
& 2015 & 3.50 tribillion & $6.8 \%$ & $17.4 \%$ & $15-20 \%$ \\
& 2016 & 2.45 tribillion & $8.5 \%$ & $4.8 \%$ & $15-20 \%$ \\
& 2017 & 2.28 tribillion & $9.1 \%$ & $5.3 \%$ & $10-12 \%$ \\
\hline
\end{tabular}

Source: CBK, 2017

\subsection{Credit Risk Management}

(Diacan 2013) stated that risk is present whenever human beings are unable to control or perfectly fore see the future. Similarly there are risks in running a business because no business man can guarantee that he will make profits rather than losses. But although we cannot measure the risks, we can to some extend measure it. The term uncertainty is used where future alternatives are not known such as in speculative ventures like the outcome of space research or of possible new inventions. Credit risk is the risk that is associated with customer default that is failed to comply with obligation to service debt. Credit risk is also the risk of a decline in the credit standing of 
counter party (Onesis, 2011).

\subsubsection{Non-performing loans}

A loan is normally defined as a non-performing when customer's payments are in arrears (Ahmed, 2014). Late payment is characterized by a non-performing loan (NPLs) rather than a defaulted loan of the borrower is still undertaking business. At the some point, irrespective of the state of the borrower, an NPL can be written down which must be funded out of the bank's capital is often at $100 \%$ of outstanding value. The bank might recover a percentage but at some later date. NPLR is the ratio of non-performing loans to total loans (Churchil, 2011). The equation can be defined as: NPLR $=$ NPLs/Total loans.

\subsubsection{Debt Collection Policies}

Effective credit collection policies are one of the necessities for financial institutions in any economic climate knowing how to encourage customers to pay their outstanding debts to financial institutions like banks on time can increase the cash flows of banks. As the loan account becomes past due or overdue the collection effort becomes personal and strict. The basic techniques are Telephone calls: If the loan client passes the due date, a telephone call may be made to the customer to request for immediate repayment and update his account. Personal visits: If the telephone call made does not result positive response, visiting his business and discussing the issue with the customer can be very effective. Letters: If the efforts made so far is unsuccessful and, a polite letter is to be served reminding the customer of his obligation to pay followed by warning letters for the action to be taken in future and its consequences. Collection letters are the first step in the collection process for past due overdue accounts. Using collection agencies: Firms can turn uncollectible accounts over collection agency or an attorney for collection the fees for this service is typically quite high, the firm may receive less than $50 \%$ on account collected in this way. Legal action: Legal action is the most stringent step in the collection process (Karkuru, 2013).

\subsection{Financial performance on commercial banks}

Performance is the accomplishment of a given task measured against present known standards of accuracy, completeness, cost and speed. Financial performance is any of the difference measures to evaluate how well a company is using its resources to generate income (Richard et.al 2009). Common examples of financial performance include operating income, earnings before interest and taxes and net asset value. It is important to note that no one measure of financial performance should be taken on its own. A commercial bank is an institution which accepts deposits, makes business loans and offers related services.

\subsubsection{Return on Assets}

Return on Assets (ROA) is a financial ratio that shows the percentage of profit a company earns in relation to its overall resources. It is commonly defined as net income divided by total assets. ROA is an indicator of how profitable a company is relative to its total assets. ROA gives an idea as to how efficient management is at using its assets to generate earnings. It is calculated by dividing a company's annual earnings by its total assets. ROA helps investors to measure how management is using its assets or resources to generate more income.

Return on Assets $=$ Net Income/Total Assets.

Table 2.2 Commercial Bank's Profitability in Kenya Name of Bank

Year

\begin{tabular}{lrrrrrr}
\hline & $\mathbf{2 0 1 3}$ & $\mathbf{2 0 1 4}$ & $\mathbf{2 0 1 5}$ & $\mathbf{2 0 1 6}$ & \multicolumn{1}{c}{$\mathbf{2 0 1 7}$} & $\mathbf{2 0 1 8}$ \\
\hline Equity Bank & $12.0 \%$ & $12.2 \%$ & $12.5 \%$ & $10.5 \%$ & $90.0 \%$ & $10.0 \%$ \\
Cooperative Bank & $11.0 \%$ & $11.5 \%$ & $11.6 \%$ & $11.0 \%$ & $10.0 \%$ & $10.5 \%$ \\
Standard Chartered Bank & $6.0 \%$ & $7.0 \%$ & $6.5 \%$ & $5.0 \%$ & $4.0 \%$ & $5.0 \%$ \\
Barclays Bank & $5.5 \%$ & $6.0 \%$ & $6.2 \%$ & $6.0 \%$ & $5.0 \%$ & $6.0 \%$ \\
\hline
\end{tabular}

Source: CBK, 2017

\subsection{Credit Market Theory}

Credit market theory was developed by Harry Markowitz in early 1050s. Credit market theory is where investors and institutions can buy debt securities such as bonds. Issuing debt securities is how governments and corporations raise capital, taking investor's money now and paying interest until they pay back the debt at maturity. A model of the neoclassical credit market postulates that the terms of credit are clear in the market. The theory postulates that if collateral and other pertinent restrictions remain as a requirement, then it is only the lending rate that determines the amount of credit that is dispensed by the banking sector. With an increasing demand for credit and a fixed supply of the same, interest rates will have to rise (Otieno, 2013). The relevance of this theory to my study is that as interest rate is regulated, it affects loans lent to the public and if lending policies are not restrictly adhered to, will lead to NPLs.

\subsection{Effect of Credit risk management and financial performance of commercial banks in Kenya}


(Kibor 2015) carried out a study on the influence of credit risk management on loan performance in commercial banks in Nakuru Town Kenya, adopted a descriptive and correlation research design and the target population constituted 37 respondents drawn from the 37 commercial banks branches in Nakuru Town. A census design was employed and a structured questionnaire was used to collect data from the respondents. A pilot study was conducted prior to undertaking the main study with aim of testing the instruments' reliability and validity. The collected data was analyzed by both descriptive and inferentially. The study established that there exists a moderating strong and positive relationship between lending policy and loan performance, and that the relationship between credit standards and loan performance was found to be positive, strong and statistically significant. It is recommended that every commercial bank should have an effective lending policy. More ever, credit standards for commercial banks should be customized to the credit worthiness of prospective borrowers.

2.7 Effect of Interest rate regulation on the relationship between loan loan lending policies and financial performance of commercial banks in Kenya.

(Munyiri 2010) carried out a study on lending policies and their effects on performance of commercial banks in Kenya. The study adopted a descriptive survey method and the population of interest was forty six (46) commercial banks in Kenya. The study used structured questionnaire to collect data from all the 46 commercial banks in Kenya and descriptive statistics was used to summarize the data. The data was presented in tables and other graphical presentations as appropriate for ease of understanding the analysis. From the findings of the study concluded that lending policies formulated by the commercial banks are customer friendly focused on customer's capability, prevailing market conditions that suit the customer needs and enables the clients to feel comfortable when borrowing from the banks. The study concluded that bank lending policies have effects on bank performance through attracting and retaining customers increasing the bank customer base, increase shareholders value, create customer satisfaction, create competitive advantage reduce loan loss defaults and increase bank profitability. The study findings showed that lending policies are customer friendly, while in practice commercial banks experience non-performing loans.

Independent Variable

Loan Lending Policies

\section{Dependant Variable}

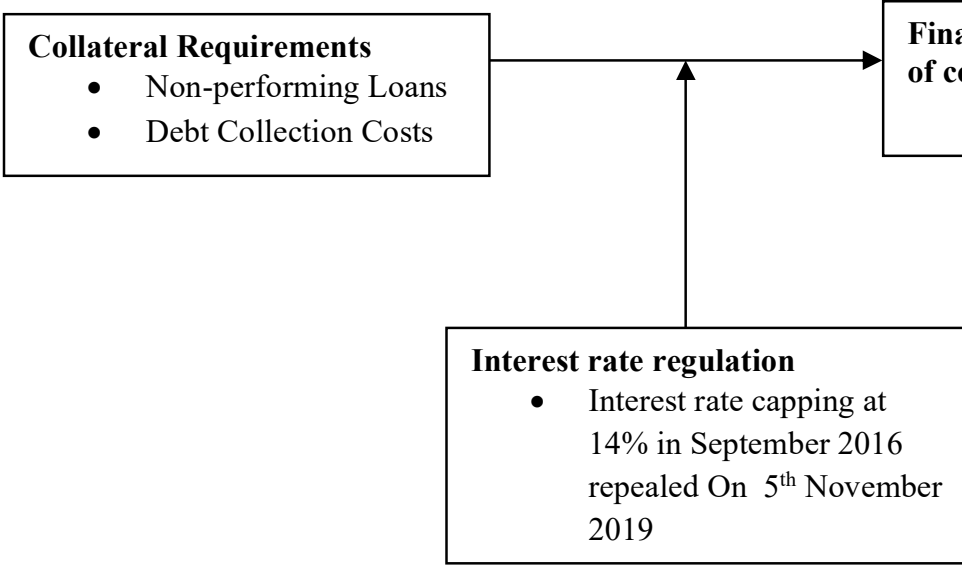

Fig 2.1 Conceptual Framework Source: Researcher 2020

\section{RESEARCH METHODLOGY 3.1 Research Design}

The study adopted descriptive research design. The descriptive research design was appropriate because it involves the collection of numerical data to describe the situation or case under the research study. The descriptive research design is a theory based method which is created by gathering, analyzing and presenting the collected data.

\subsection{Area of Study}

The research study area was all the 43 commercial banks registered in Kenya in Nairobi city which is the Headquarter of all the 43 commercial banks in Kenya.

\subsection{Target Population}

The target population of this study was 129 employees of all the 43 commercial banks registered in Kenya that is: 43 Bank managers 43 operations managers and 43 credit managers. 
Table 3.1 Target Population

\begin{tabular}{lc}
\hline DESIGNATION OF BANK OFFICERS & NUMBER OF OFFICERS \\
\hline Bank Managers & 43 \\
Credit Managers & 43 \\
Operations Managers & 43 \\
Total & $\mathbf{1 2 9}$ \\
\hline
\end{tabular}

Source: Research 2020

\subsection{Sampling Procedure and Sample Size}

The study adopted a Census survey Method and purposive sampling method. The number of respondents in this study was 129 officers of all the 43 commercial banks registered in Kenya during the period in the period of study (2013 - 2018). The respondents were 43 bank managers 43 operations managers and 43 credit managers of all the 43 commercial banks registered in Kenya.

\subsection{Data Collection Procedure}

After receiving a letter of authorization for data collection from the post graduate school, Document Analysis Guide was used to collect secondary quantitative data on the effect of interest rate regulation on the relationship between loan lending policies and financial performance of commercial banks. The researcher collected primary data from the respondents of the employees of the commercial banks in Kenya who handle borrowers.

\subsection{Data Analysis}

Quantitative panel data analysis was adopted for conducting the econometric modeling. Panel data analysis for this study was executed by using both descriptive and inferential statistics techniques. The data collected was edited, coded and the analyzed using descriptive statistics. SPSS Version 22 software was used to generate descriptive statistics by way of mean, frequency tables and percentages. Inferential statistics was analyzed using multiple linear regression analysis model to test the statistical significance of the various independent variables loan lending policies (credit risk) on the dependent variables of financial performance of commercial banks (Return on assets) together with moderating variable (Interest rate regulation) and the results was displayed on tables.

\subsection{Description on the data and variable definition}

Secondary quantitative data on the effect of interest rate regulation, loan lending policies components and financial performance of commercial banks was obtained through Document Analysis Guide.

\subsubsection{Descriptive Analysis}

The mean and median which are the measures of Central tendency were used to indicate the middle and common occurring points in the data set for both explanatory and dependent variables. On the other hand, standard deviation is the measures of dispersion and was used to indicate how spread of the data around the mean. These measures were used to show the trend in commercial banks interest rate regulation, loan lending policies and financial performance of commercial banks during the study period 2013 to 2015 before the capping of interest rates and 2016 to 2018 after the capping of interest rates.

\subsubsection{Correlation Analysis}

Correlation analysis was used to determine the direction of and strength of association between variables. This was done before conducting regression analysis or model estimation. Given that the study sought to establish the effect of interest rate regulation on the relationship between loan lending policies and performance of commercial banks, Pearson (r) correlation coefficient was computed given the interval nature of the data and the need to test the direction and strength of association that exist among the study variables. Variance inflation factor (VIF) test was also performed for each explanatory variable entering the regression models to test for multi-co linearity.

\subsection{Diagnostic Tests for Regression Analysis}

The diagnostic tests for regression analysis was done using the following methods: Normality, co linearity/unit root test, stationarity, heteroscedasticity and multicoilinearity tests to evaluate whether the model used in the study is appropriate to address the research objectives and also to fulfill the assumption of classical linear regression model that is; its suitability, reliability and accuracy.

\subsection{Empirical Models}

A model is a simplified view of reality designed to enable a researcher describe the essence and inter relationship within the system or phenomenon (Onmumere, 2015).

To measure the direct effect of the independent variables on the dependent variable the study utilized the 
model proposed by Athanasoglou et al (2006) and as used by Simeyo (2018). The models were modified and speficified as follows:

$$
Y_{i t}=\alpha_{i} Y_{i t-}+\beta_{1} X_{1}+\beta_{2} X_{2}+u_{i t}
$$

$Y_{i t}$ : represent the dependent variable and measures ROA of bank $\mathrm{i}$ at time $\mathrm{t}$, with $i=1 \ldots \mathrm{n}$ and $t=1, \ldots \mathrm{T}$. $N=$ $\sum_{t=1}^{t} n_{i}$ represents the number of cross-sectional observations and $\mathrm{T}$ the length of the sample period.

$Y_{i t-1}$ is one year time lag ROA

$\mathrm{X}_{1}=$ Non-performing Loans (NPLs)

$\mathrm{X}_{2}=$ Debt collection Costs $(\mathrm{DCC})$

$\beta_{1} \ldots \mathrm{B}_{6}=$ Regression coefficient

$u_{i t}, e_{i t}$ and $v_{i t}$ are error terms

To determine the effect of interest rate regulation on the relationship between loan lending policies and financial performance of commercial banks in Kenya, the student t-test was first used to establish whether there was a statistically significant difference in the study variables before and after the interest rate capping and then Entity de-meaned OLS Fixed Effects estimation approach combined with changes specifications in which the difference in the mean ROA between the period before interest rate capping (2013-2015) and that after the interest rate capping (2016-2018) was regressed on the difference in independent variables between those two periods.

For model formulation, let $\mathbf{t}$ denote the period when interest rate capping came into effect such that ( $\mathrm{t}-1)$ denotes the period before capping and $(\mathrm{t}+1)$ the period after capping.

First, the study applied the student t-test to establish whether there was a significant difference in means of ROA, NPLs and DCC before and after the interest rate capping.

For ROA, the t-statistic was:

$$
T=\frac{\overline{y_{1}}-\overline{y_{2}}}{\sqrt{\frac{\sigma_{1}^{2}}{n_{1}}+\frac{\sigma_{2}^{2}}{n_{2}}}}
$$

Where $\overline{y_{1}}$ is the mean ROA before capping and $\overline{y_{2}}$ is the mean ROA after capping of interest rate. $\sigma_{1}^{2}$ is the variance of ROA before capping and $\sigma_{2}^{2}$ is the variance of ROA after capping. $n_{1}$ is total number of observation for the period before capping while $n_{2}$ is the total number of observations after capping. At $5 \%$ level of significance, the difference in the means will be statistically significant if the difference $\left(\overline{y_{1}}-\overline{y_{2}}\right)$ is more than $1.96 \times \sqrt{\frac{\sigma_{1}^{2}}{n_{1}}+\frac{\sigma_{2}^{2}}{n_{2}}}$. For the independent variables say $X_{j}$, the t-test statistic was:

$$
T=\frac{\bar{X}_{j 1}-\bar{X}_{j 2}}{\sqrt{\frac{\sigma_{j 1}^{2}}{n_{1}}+\frac{\sigma_{j 2}^{2}}{n_{2}}}}
$$

At $5 \%$ level of significance, the difference in the means will be statistically significant if the difference $\left(\bar{X}_{j 1}-\bar{X}_{j 2}\right)$ is more than $1.96 \times \sqrt{\frac{\sigma_{j 1}^{2}}{n_{1}}+\frac{\sigma_{j 2}^{2}}{n_{2}}}$.

To establish whether interest rate regulation has an effect on the relationship between credit risk managment and financial performance of commercial banks in Kenya, the following models was used:

Where

$$
\left(\bar{Y}_{i, t+1}-\bar{Y}_{i, t-1}\right)=\beta 0+\beta_{1}\left(\bar{X}_{i 1, t+1}-\bar{X}_{i 1, t-1}\right)+\beta_{2}\left(\bar{X}_{i 2, t+1}-\bar{X}_{i 2, t-1}\right)+u_{i t} \ldots 4.1
$$

$$
\begin{aligned}
& \bar{Y}_{\mathrm{i}, \mathrm{t}-1}=\frac{1}{\mathrm{t}_{1}} \sum_{\mathrm{t}=1}^{\mathrm{t}_{1}} \mathrm{Y}_{\mathrm{it}}=\text { mean ROA for bank } \mathrm{i} \text { during the "before interest capping" period } \\
& \overline{\mathrm{Y}}_{\mathrm{i}, \mathrm{t}+1}=\frac{1}{\mathrm{t}_{2}} \sum_{\substack{\mathrm{t}=1 \\
\mathrm{t}_{1}}}^{\mathrm{Y}_{\mathrm{it}}}=\text { mean ROA for bank i during the "after interest capping" period } \\
& \overline{\mathrm{X}}_{\mathrm{i} 1, \mathrm{t}-1}=\frac{1}{\mathrm{t}_{1}} \sum_{\mathrm{t}=1}^{\mathrm{t}_{2}} \mathrm{X}_{\mathrm{it}}=\text { mean NPLS for bank i during the "before interest capping" period } \\
& \overline{\mathrm{X}}_{\mathrm{i} 1, \mathrm{t}+1}=\frac{1}{\mathrm{t}_{2}} \sum_{\mathrm{t}=1} \mathrm{X}_{\mathrm{it}}=\text { mean NPLS for bank i during the "after interest capping" period }
\end{aligned}
$$




$$
\begin{gathered}
\overline{\mathrm{X}}_{\mathrm{i} 2, \mathrm{t}-1}=\frac{1}{\mathrm{t}_{1}} \sum_{\mathrm{t}=1}^{\mathrm{t}_{1}} \mathrm{X}_{\mathrm{it}}=\text { mean DCC for bank i during the "before interest capping" period } \\
\overline{\mathrm{X}}_{\mathrm{i} 2, \mathrm{t}+1}=\frac{1}{\mathrm{t}_{2}} \sum_{\mathrm{t}=1} \mathrm{X}_{\mathrm{it}}=\text { mean DCC for bank i during the "after interest capping" period }
\end{gathered}
$$

\section{FINDINGS AND DISCUSSIONS}

\subsection{Descriptive Statistics}

This section contains the descriptive statistics of all the variables included in the analysis. According to Kothari (2014), descriptive statistics provide important statistical measures that are used to summarize research data. Table 4.1 presents the summary statistics for Non-performing loans, Debt Collection Costs and Return on Assets for the years 2013 to 2018 .

\begin{tabular}{|c|c|c|c|c|c|c|}
\hline & 2013 & 2014 & 2015 & 2016 & 2017 & 2018 \\
\hline \multicolumn{7}{|c|}{ Credit risk management (Non-performing loans (in Kshs.000,000)) } \\
\hline Mean & 1,012 & 872 & 602 & 19,200 & 20,790 & 20,000 \\
\hline Std. Dev. & 1,102 & 2,204 & 3,302 & 20,111 & 20,640 & 31,211 \\
\hline Minimum & 1,120 & 1,420 & 1,221 & 2,103 & 6,103 & 7,621 \\
\hline Maximum & 18,135 & 10,320 & 8,215 & 2,012 & 11,021 & 15,150 \\
\hline \multicolumn{7}{|c|}{ Debt collection costs (in Kshs.000,000) } \\
\hline Mean & 1,360 & 830 & 722 & 1,032 & 2,340 & 5,103 \\
\hline Std. Dev. & 204 & 820 & 2,340 & 9,100 & 10,300 & 11,320 \\
\hline Minmum & 1,345 & 2,012 & 2,630 & 6,701 & 5,021 & 6,320 \\
\hline Maximum & 3,103 & 6,120 & 3,781 & 9,134 & 8,010 & 93,210 \\
\hline \multicolumn{7}{|c|}{ Return on Assets( $(\%)$} \\
\hline Mean & 9.09 & 9.10 & 8.10 & 8.22 & 5.88 & 5.17 \\
\hline Std. Dev. & 12.30 & 11.20 & 21.12 & 21.10 & 22.22 & 13.20 \\
\hline Minimum & 2.10 & 6.11 & 6.10 & 7.10 & 2.15 & 2.32 \\
\hline Maximum & 12.12 & 13.10 & 11.10 & 16.10 & 12.20 & 10.22 \\
\hline
\end{tabular}

Table 4.1: Descriptive Statistics (2013 to 2018)

Source: Research 2020

\subsection{Interpretation of the Results}

Table 4.1 above shows the secondary data on Document Analysis Guide spread from the mean, standard deviation, minimum and maximum of the descriptive statistics of secondary data. Non-performing loans had the highest mean of Ksh.20790 in 2017 and a standard deviation of Ks.31211 in 2018. The debt collection costs had a highest mean of 5,103 in 2018, highest standard deviation of 11,320 in 2018 . The highest mean for ROA was $9.10 \%$ in 2014 with a standard deviation of $22.22 \%$ in 2017 . This is the data that was collected from the financial (annual reports of commercial banks using Document Analysis Guide. The results show that before the interest rate capping, all the variables had lower values for period 2013 to 2015 but it increased in the period 2016 to 2018 when there was interest rate capping. This implies that interest capping has either positive or negative impact on the financial performance of commercial banks.

\subsection{Panel Specification Test}

To determine the suitability of the panel data for statistical analysis, various tests which include, panel unit root test, granger-casuality test, multicollinearity test, panel-level heteroscedasticity test, serial correlation test and the Hausman effect test were conducted. In addition, panel cointegration test was conducted to determine if the variables used in the study had along run association.

\subsubsection{Unit root test}

To establish whether the data employed in this study is stationary or not, the study employed the Fisher- type Augmented Dickey and Fuller (ADF) and Fisher- type Phillips and Perro (PP) (Choi, 2001) for the purpose of a wider comparison, thus, the decision rule here is that if the p value is less than $0.05 \mathrm{H} 0$ is rejected and the acceptance of $\mathrm{H} 1$ and vice versa. 
Table 4.2: Stationarity test results

\begin{tabular}{|l|l|l|l|l|}
\hline Variable & Test & Statistic & P' & Decision \\
\hline NPLS & $\begin{array}{l}\text { Augmented- } \\
\text { Dickey Fuller }\end{array}$ & -14.43681 & .0000 & Stationary \\
\cline { 2 - 5 } & Phillips-Perron & -14.17069 & .0000 & Stationary \\
\hline \multirow{5}{*}{ DCC } & $\begin{array}{l}\text { Augmented- } \\
\text { Dickey Fuller }\end{array}$ & -6.99586 & .0000 & Stationary \\
\cline { 2 - 5 } & Phillips-Perron & -21.52153 & .0000 & Stationary \\
\hline \multirow{5}{*}{ ROA } & $\begin{array}{l}\text { Augmented- } \\
\text { Dickey Fuller }\end{array}$ & -20.24955 & .0000 & Stationary \\
\cline { 2 - 5 } & Phillips-Perron & -20.25324 & .0000 & Stationary \\
\cline { 2 - 5 } & Phillips-Perron & 188.793 & .0000 & Stationary \\
\hline
\end{tabular}

\section{Source: Resarch 2020}

The output on Table 4.2 was based on the ADF and PP panel unit root test results carried out on each of the variables and the entire group. As may be seen from the earlier formulated hypothesis, the two methods test the same null hypothesis of non-stationarity. The result indicated that the null hypothesis of "non-stationarity" was rejected for all the variables since the associated $p$-values were less than the $5 \%$ statistical level of significance and was consistent with the two methods applied for comparison. It can, therefore, be deduced that all the variables used in the study were stationary thereby informing the acceptance of the alternative hypothesis.

\subsubsection{Serial correlation test}

The Arellano-Bond Serial Correlation test results for the panel data are showm in table 4.3

Table 4.3: Arellano-Bond Serial Correlation Test

Arellano-Bond Serial Correlation Test

Equation: Untitled

Date: 09/25/20 Time: 17:50

Sample: 20132018

Included observations: 57

\begin{tabular}{ccccr}
\hline \hline Test order & m-Statistic & rho & SE(rho) & Prob. \\
\hline \hline AR(1) & -1.462474 & -0.757519 & 0.517971 & 0.1436 \\
AR(2) & -1.420482 & -0.525278 & 0.369789 & 0.1555 \\
\hline \hline
\end{tabular}

H0: No first-order autocorrelation tests carried out at 5\% significance level

The results show that the m-statistic is not statistically significant at $5 \%$ level of significance. This implied that the null hypothesis is not rejected for the model hence there doesn't exist first-order autocorrelation nor second-order autocorrelation in the panel data employed in the analysis.

4.3.3 Multicollinearity test

In the study the variance inflation factor (VIF) was used as an indicator of multicollinearity. As a rule of thumb, lower levels of variance inflation factor (VIF) are desirable as higher levels of VIF are known to affect adversely the results associated with multiple regression analysis. Garson (2012) asserts that the rule of thumb is that if VIF $>4.0$ multicollinearity is a problem. The results of the analysis are shown in table 4.4 below:

Table 4.4: Test for Multicollinearity

\begin{tabular}{|l|l|l|}
\hline Variable & VIF & $1 /$ VIF \\
\hline NPLS & 1.92 & 0.521994 \\
\hline DCC & 1.14 & 0.880207 \\
\hline
\end{tabular}

Source: Reseach 2020

As can be observed in table 4.6, NPLS had a VIF value of 1.92 and DCC had a VIF value of 1.14. The results were established to be less than 10 and thus according to Field (2009), there is no Multicollinearity. This is further supported by the values of the correlation matrix in table 4.5

Table 4.5: Correlation Matrix for the independent variables

\begin{tabular}{|l|l|l|l|}
\hline & ROA & NPLS & DCC \\
\hline ROA & 1.000 & & \\
\hline NPLS & -.551 & 1.000 & \\
\hline DCC & .092 & -.373 & 1.000 \\
\hline
\end{tabular}

Source: Research 2020

The correlation between the independent variables are all less than 0.7 hence indicating the absence of multicolinearity (Tabachnick\&Fidell, 2007). The established correlations between the ROA and loan lending 
policies indicators (NPLS and DCC) were negative and moderate since they were all above 0.3 and less than 0.5 . For the loan underwriting indicators (NPLS and DCC), the study established a negative strong correlation between ROA and NPLS (-0.551) and a very weak correlation between ROA and DCC (Chang et al., 2010).

\subsubsection{Hausman effect test}

To establish which estimation effects (between fixed and random) provided superior results for the study, Hausman test was carried out for the specified panel regression model. The test was conducted against the null hypothesis that random effect model was the preferred model. If the chi-square statistic was significant at $5 \%$ significance level, the null hypothesis is rejected; otherwise, the null hypothesis is accepted.

Table 4.6: Hausman test result

Correlated Random Effects - Hausman Test

Equation: Untitled

Test cross-section random effects

\begin{tabular}{lccr}
\hline \hline Test Summary & Chi-Sq. Statistic & Chi-Sq. d.f. & Prob. \\
\hline \hline Cross-section random & 3.773616 & 6 & 0.4375 \\
\hline \hline
\end{tabular}

Table 4.6 display the Hausman specification test results for panel regression equation. The test results show that the chi-square statistics for the panel equation is not statistically significant at $5 \%$ level as indicated by the $\mathrm{p}$ values of 0.4375 . The study, therefore, rejects the null hypothesis that the random effects estimation was appropriate for the model at 5\% significance level. Nevertheless, the fixed effect (FEM) and random effect (REM) estimators are also biased and inconsistent unless the number of time periods is large $n \geq 30$ (Baltagi, 2002). The study therefore opted to employ the panel equations for dynamic GMM.

\subsection{Inferential Statistics}

\subsubsection{Effect of credit risk management on financial performance of commercial banks in Kenya}

The first objective was to establish the relationship between credit risk management and financial performance of commercial banks in Kenya. The formulated null hypothesis was that credit risk management has no significant effect on the financial performance of commercial banks. The results of the analysis are presented in Table 4.7

Table 4.7: Two-step dynamic GMM estimated results of the effect of Credit risk management on Firm Value

Dependent Variable: ROA

Method: Panel Generalized Method of Moments

Transformation: First Differences

Date: 09/03/20 Time: 2:23

Sample (adjusted): 2013- 2018

Periods included: 6

Cross-sections included: 43

Total panel (balanced) observations: 258

White period instrument weighting matrix

White period standard errors \& covariance (d.f. corrected)

Instrument specification: @DYN(ROA,-2) ROANPLS,DCC

Constant added to instrument list

\begin{tabular}{|c|c|c|c|c|}
\hline Variable & Coefficient & Std. Error & t-Statistic & Prob. \\
\hline $\operatorname{ROA}(-1)$ & 0.00154 & 0.000480 & 3.2266 & 0.0000 \\
\hline NPLS & -0.31481 & 0.049661 & -6.3390 & 0.0000 \\
\hline $\mathrm{DCC}$ & 0.04244 & 0.041213 & 1.02986 & 0.0741 \\
\hline \multicolumn{5}{|c|}{ Effects Specification } \\
\hline \multicolumn{5}{|c|}{ Cross-section fixed (first differences) } \\
\hline Mean dependent var & -0.122250 & S.D. dependent var & & 1.896549 \\
\hline S.E. of regression & 2.017809 & Sum squared resid & & 1290.682 \\
\hline J-statistic & 38.12567 & Instrument rank & & 39 \\
\hline $\operatorname{Prob}(J-s t a t i s t i c)$ & 0.372955 & & & \\
\hline
\end{tabular}


The coefficient of lagged ROA for model 2 is 0.00154 . Thus the lower bound of lagged return on Assets in the GMM specification should be 0.00154 . On the relationship between non-performing loans and ROA, the study established a negative relationship significant at 5\% level of significance. On the relationship between debt collection costs and ROA, the study established a positive relationship which was however not significant at 5\% level of significance. The regression equation for the relationship therefore takes the form

$$
R O A_{i t}=0.00154 R O A_{i t-1}-0.31481 D C C_{i t}+0.04244 L T_{i t}
$$

Hypothesis one $\left(\mathrm{H}_{1 \mathrm{a}}\right)$ states that non-performing loans has no significant relationship with ROA of commercial banks. The $t$-test results $(t=-6.3390 ; \mathbf{p}=\mathbf{0 . 0 0 0})$ indicate that the relationship between NPLS and ROA is tatistically significant. This finding rejected the stated null hypothesis with $95 \%$ confidence and concluded that non-performing loans have a significant effect on the financial performance of commercial banks.

Hypothesis one $\left(\mathrm{HO}_{2 b}\right)$ stated that debt collection cost has no significant relationship with ROA of commercial banks. The t-test results $(\mathrm{t}=1.02986 ; \mathbf{p}=\mathbf{0} .0741)$ indicate that the relationship between debt collection costs and ROA is not statistically significant. This finding fails to reject the stated null hypothesis with $95 \%$ confidence and concluded that debt collection cost has a non-significant effect on the financial performance of commercial banks.

The Hansen $\mathrm{J}$ statistic for the model is 38.12567 with a corresponding p-value of 0.372955 which is greater than 0.1 . Therefore, the null hypothesis of the validity of the instruments is not rejected at one per cent level of significance. Therefore, the instruments employed by the model were appropriate.

Further to secondary data, Primary data was collected on how poor credit risk managment affect the financial performance of commercial banks in Kenya. 129 questionnaires were distributed to 43 bank managers, 43 credit managers and 43 operations managers but only 112 were returned representing $86.82 \%$. Table 4.8 displays the views of the respondents on the statements.

Table 4.8: Credit risk Management and Financial Performance of commercial banks in Kenya

\begin{tabular}{|c|c|c|c|c|c|c|c|}
\hline Statement & $\begin{array}{l}\text { Not } \\
\text { At all \% }\end{array}$ & $\begin{array}{l}\text { To a } \\
\text { Less } \\
\text { extent \% }\end{array}$ & $\begin{array}{l}\text { To a } \\
\text { Moderate } \\
\text { extent \% }\end{array}$ & $\begin{array}{l}\text { To a } \\
\text { Great } \\
\text { extent \% }\end{array}$ & $\begin{array}{c}\text { To a } \\
\text { Greater } \\
\text { extent \% }\end{array}$ & Mean & Std. Dev. \\
\hline Weak loan & & & & & & & \\
\hline $\begin{array}{l}\text { Lending policies } \\
\text { Influence loan }\end{array}$ & 2.7 & 6.8 & 21.9 & 42.5 & 26.0 & 3.82 & 0.991 \\
\hline $\begin{array}{l}\text { Repayment ability } \\
\text { The quality of credit officers } \\
\text { Determine the nature of } \\
\text { Appraisal and extent of NPLs }\end{array}$ & 2.7 & 4.1 & 21.6 & 35.1 & 36.5 & 3.99 & 1.000 \\
\hline $\begin{array}{l}\text { Appraisal and extent of NPLS } \\
\text { The term of the loan given } \\
\text { Influence loan repayment }\end{array}$ & 4.1 & 1.4 & 33.8 & 47.3 & 13.5 & 3.65 & 0.883 \\
\hline $\begin{array}{l}\text { Poor loan lending policies } \\
\text { Lead to debt collection costs }\end{array}$ & 0.00 & 9.5 & 35.1 & 32.4 & 23.0 & 3.69 & 0.935 \\
\hline $\begin{array}{l}\text { Loan lending producres } \\
\text { Assist in reducing NPLs }\end{array}$ & 1.4 & 13.5 & 39.2 & 27.0 & 18.9 & 3.49 & 0.996 \\
\hline $\begin{array}{l}\text { Loan lending in terms of } \\
\text { NPLS, DCC affects ROA } \\
\text { Loan lending policies }\end{array}$ & 0.00 & 12.2 & 24.3 & 32.4 & 31.1 & 3.82 & 1.012 \\
\hline $\begin{array}{l}\text { Assisted in minimizing DCC } \\
\text { In banks }\end{array}$ & 2.7 & 4.1 & 21.9 & 52.1 & 19.2 & 3.81 & 0.892 \\
\hline $\begin{array}{l}\text { Loan lending policies has } \\
\text { Increased profits in banks } \\
\text { Average Mean }\end{array}$ & 2.7 & 8.1 & 29.7 & 39.2 & 20.3 & $\begin{array}{l}3.66 \\
\mathbf{3 . 7 4 2 3}\end{array}$ & $\begin{array}{l}0.983 \\
\mathbf{0 . 9 6 1 5}\end{array}$ \\
\hline
\end{tabular}

\section{Source: Research 2020}

Data on table 4.8 show responses on statements regarding the effect of credit risk management on financial performance of commercial banks in Kenya. All the responses in all the statements indicated that credit risk management in terms of NPLs and DCC afftects the financial performance of commercial banks negatively as it affects the bank's liquidity position. The mean score of response regarding NPLs was 3.7423 on a 5 point scale and the overall average standard deviation was 0.9615 .

4.4.2 Effect of interest rate regulation on the relationship between loan lending policies and financial performance of commercial banks in Kenya.

The second objective sought to determine the effect of interest rate regulation on the relationship between loan lending policies and financial performance of commercial banks in Kenya. The study data were divided into two periods: the period before the interest rate capping (2013-2015) and the period after the interest rate capping (2016- 
2018). The independent samples T-test was used to establish if there was a significant difference in the means of the study variables and pooled regression with differencing was used to establish whether changes in ROA between the two periods was a result of the changes in the explanatory variables between the two periods.

4.4.2b Group Statistics for ROA and Loan Lending Policies practices before and after interest rate capping Table 4.9: Group Statistics for ROA and Loan Portfolio management practices before and after interest rate capping

\begin{tabular}{|l|l|l|l|l|l|}
\hline VARIABLE & GROUP & $\mathrm{N}$ & MEAN & SD & SE.MEAN \\
\hline \multirow{2}{*}{ ROA } & BEFORE CAP (\%) & 129 & 8.8974401 & 1.995 & .425 \\
\cline { 2 - 6 } & AFTER CAP (\%) & 86 & 5.2565423 & 3.102 & .661 \\
\hline \multirow{2}{*}{ DCC } & $\begin{array}{l}\text { BEFORE CAP } \\
(\text { KSHS'.000,000) }\end{array}$ & 129 & 82.87 & 32.273 & 6.633 \\
\cline { 2 - 6 } & $\begin{array}{l}\text { AFTER CAP } \\
\text { KSHS'000,000) }\end{array}$ & 86 & 20.43 & 38.165 & 8.857 \\
\hline & $\begin{array}{l}\text { BEFORE CAP } \\
(\text { KSHS'000,000) }\end{array}$ & 129 & 2368.67 & 9.118 & 8.975 \\
\cline { 2 - 6 } & $\begin{array}{l}\text { AFTER CAP } \\
(\text { KSHS'000,000) }\end{array}$ & 86 & 1388.81 & 7.347 & 1.853 \\
\hline
\end{tabular}

\section{Source: Research 2020}

The results presented in Table 4.9 depicts that the mean ROA before the interest rate capping of 8.8974401 and standard deviation of 1.995 was higher than the mean ROA after the interest rate capping in 2016 (Mean=5.2565423, SD=3.102). The results depicts that the introduction of interest rate capping resulted to a decline in the ROA of the commercial banks in Kenya. With regard to NPLS, the study etablished a mean of Kshs 2529.3 million before the introduction of interest rate capping and a mean of Kshs1089.5 million after the interest rate capping with values deviating from these means by 15.256 and 11.546 respectively. Fot debt collection costs, means of Kshs2368.67 million ( $\mathrm{SD}=9.118)$ and Kshs1388.81 million ( $\mathrm{SD}=7.347$ ) were obtained for the period before and after interest rate capping periods which indicates that the introduction of interest rate regulation consequently led to more emphasis on NPLS and debt collection costs for the commercial banks in Kenya.

The results for the independent samples t-test for ROA are as shown in table 4.10 below:

Table 4.10: Independent Samples T-test for the Difference in the Means of ROA

\begin{tabular}{|c|l|l|l|l|l|l|l|l|}
\hline \multicolumn{2}{|c|}{} & \multicolumn{2}{|c|}{$\begin{array}{c}\text { Levene's Test for } \\
\text { Equality of } \\
\text { Variances }\end{array}$} & \multicolumn{3}{|c|}{ t-test for Equality of Means } \\
\cline { 2 - 8 } & F & \multicolumn{1}{|c|}{ Sig. } & T & Df & $\begin{array}{l}\text { Sig. (2- } \\
\text { tailed) }\end{array}$ & $\begin{array}{l}\text { Mean } \\
\text { Diff. }\end{array}$ & $\begin{array}{l}\text { SE } \\
\text { Diff. }\end{array}$ \\
\hline ROA & $\begin{array}{l}\text { Equal } \\
\text { variances } \\
\text { assumed }\end{array}$ & 3.193 & .031 & 3.815 & 41 & .020 & 3.64089 & .78629 \\
\cline { 2 - 9 } & $\begin{array}{l}\text { Equal } \\
\text { variances not } \\
\text { assumed }\end{array}$ & & 3.815 & 36.836 & .020 & 3.64089 & .78629 \\
\hline
\end{tabular}

\section{Source: Research 2020}

The t-test results for the difference in the means of ROA between the two periods shown in table 4.10 shows that a $t$-test value of 3.815 together with $p$-value of 0.020 were obtained. This indicated that the difference in the mean ROA before and after the interest rate capping was statististically significant. The results imply that the introduction of interest rates regulation led to a significant change in the profitability of the banks with the period after the capping registering smaller profitability values than the period before the capping. This also points to the fact that banks relied majorly on the higher interest rates charged for their profitability margins hence the need for diversification of the focus to other profitability drivers.

4.4.2.1 Effect of Interest rate regulation on the relationship between management of Credit risk management and financial performance of commercial banks in Kenya

To establish the effect of interest rate regulation on the relationship between credit risk management and financial performance of commercial banks, the study first applied the independent samples t-test to establish whether there was a significant difference in the means of NPLS and DCC for the two periods (before interest rate capping (2013-2015) and that after the interest rate capping (2016-2018)) and then applied pooled OLS regression analysis of the difference in the ROA between the period before interest rate capping (2013-2015) and that after the interest rate capping (2016-2018) on the difference in NPLS and DCC between those two periods i.e. The results for the independent samples t-test for NPLS and DCC are as shown in table 4.11 below: 
Table 4.11: Independent Samples T-test for the Difference in the Means of Credit risk management measures

\begin{tabular}{|c|c|c|c|c|c|c|c|c|}
\hline \multicolumn{9}{|c|}{ Independent Samples Test } \\
\hline & & \multicolumn{2}{|c|}{$\begin{array}{l}\text { Levene's Test for } \\
\text { Equality of } \\
\text { Variances }\end{array}$} & \multicolumn{5}{|c|}{ t-test for Equality of Means } \\
\hline & & $\mathrm{F}$ & Sig. & $\mathrm{T}$ & Df & $\begin{array}{l}\text { Sig. (2- } \\
\text { tailed) }\end{array}$ & $\begin{array}{l}\text { Mean } \\
\text { Diff. }\end{array}$ & $\begin{array}{l}\text { SE } \\
\text { Diff. }\end{array}$ \\
\hline \multirow[t]{2}{*}{ NPLS } & $\begin{array}{l}\text { Equal } \\
\text { variances } \\
\text { assumed } \\
\end{array}$ & 3.099 & .003 & 4.500 & 84 & .000 & 62.47 & .28703 \\
\hline & $\begin{array}{l}\text { Equal } \\
\text { variances not } \\
\text { assumed }\end{array}$ & & & 4.500 & 77.836 & .000 & 62.47 & 28703 \\
\hline \multirow[t]{2}{*}{$\mathrm{DCC}$} & $\begin{array}{l}\text { Equal } \\
\text { variances } \\
\text { assumed } \\
\end{array}$ & .107 & .743 & .317 & 84 & .751 & .07055 & .22269 \\
\hline & $\begin{array}{l}\text { Equal } \\
\text { variances not } \\
\text { assumed } \\
\end{array}$ & & & .317 & 77.836 & .751 & .07055 & .22269 \\
\hline
\end{tabular}

\section{Source: Research 2020}

The test for the difference in means of NPLS and DCC before and after interest capping indicate that the difference in the means of NPLS between the two periods was statistically significant $(t=4.500, p=.000)$ at $5 \%$ level of significance. However, the difference in the mean of DCC between the two periods was not statistically significant $(\mathrm{t}=.317, \mathrm{p}=.751)$ at $5 \%$ level of significance. This indicates that the introduction of interest capping caused sigficant changes in the non-performing loans for the commercial banks but caused no significant difference in debt collection costs.

The effect of interest rate regulation on the relationship between loan lending policies and ROA was established by Entity de-meaned OLS Fixed Effects estimation approach combined with changes specifications in which the difference in the mean ROA between the period before interest rate capping (2013-2015) and that after the interest rate capping (2017-2018) is regressed on the difference in NPLS and DCC between those two periods i.e.

$$
\left(\bar{Y}_{i, t+1}-\bar{Y}_{i, t-1}\right)=\beta 0+\beta_{3}\left(\bar{X}_{i 3, t+1}-\bar{X}_{i 3, t-1}\right)+\beta_{4}\left(\bar{X}_{i 4, t+1}-\bar{X}_{i 4, t-1}\right)+e_{i t} \ldots 3.1
$$

Where

$\bar{Y}_{i, t-1}=\frac{1}{t_{1}} \sum_{t=1}^{t_{1}} Y_{i t}=$ mean ROA for bank i during the "before interest capping" period $\bar{Y}_{i, t+1}=\frac{1}{t_{2}} \sum_{t=1}^{t_{2}} Y_{i t}=$ mean ROA for bank i during the "after interest capping" period

$$
\begin{aligned}
& \overline{\mathrm{X}}_{\mathrm{i}, \mathrm{t}-1}=\frac{1}{\mathrm{t}_{1}} \sum_{\mathrm{t}=1}^{\mathrm{t}_{1}} \mathrm{X}_{\mathrm{i} 3 \mathrm{t}}=\text { mean NPLS for bank i during the "before interest capping" period } \\
& \overline{\mathrm{X}}_{\mathrm{i} 3, \mathrm{t}+1}=\frac{1}{\mathrm{t}_{2}} \sum_{\substack{\mathrm{t}=1 \\
\mathrm{t}_{1}}} \mathrm{X}_{\mathrm{i} 3 \mathrm{t}}=\text { mean NPLS for bank i during the "after interest capping" period } \\
& \overline{\mathrm{X}}_{\mathrm{i} 4, \mathrm{t}-1}=\frac{1}{\mathrm{t}_{1}} \sum_{\mathrm{t}=1}^{\mathrm{t}_{2}} \mathrm{X}_{\mathrm{i} 4 \mathrm{t}}=\text { mean DCC for bank i during the "before interest capping" period } \\
& \overline{\mathrm{X}}_{\mathrm{i} 4, \mathrm{t}+1}=\frac{1}{\mathrm{t}_{2}} \sum_{\mathrm{t}=1} \mathrm{X}_{\mathrm{i} 4 \mathrm{t}}=\text { mean DCC for bank i during the "after interest capping" period }
\end{aligned}
$$

The regression analysis results are shown in table 4.12 . 
Table 4.12: Regression model results for Credit risk management and ROA

Model

Summary

\begin{tabular}{|c|c|c|c|c|c|c|}
\hline Model & $\mathbf{R}$ & R Square & $\begin{array}{l}\text { Adjusted R } \\
\text { Square }\end{array}$ & $\begin{array}{l}\text { Std. Error of } \\
\text { the estimate }\end{array}$ & & \\
\hline 1 & $.605^{\mathrm{a}}$ & .366 & .361 & .468 & & \\
\hline \multicolumn{7}{|l|}{ ANOVA } \\
\hline Model & & Sum of Squares & $\mathrm{Df}$ & $\begin{array}{l}\text { Mean } \\
\text { Square }\end{array}$ & $\mathbf{F}$ & Sig. \\
\hline & $\begin{array}{l}\text { Regression } \\
\text { Residual } \\
\text { Total }\end{array}$ & $\begin{array}{l}51.677 \\
76.525 \\
128.202\end{array}$ & $\begin{array}{l}2 \\
40 \\
42\end{array}$ & $\begin{array}{l}25.8385 \\
1.9131\end{array}$ & 13.506 & .0017 \\
\hline \multicolumn{7}{|l|}{ Coefficients } \\
\hline Model & & $\begin{array}{l}\text { Unstandardized } \\
\text { B coefficients }\end{array}$ & $\begin{array}{l}\text { Std. } \\
\text { Error }\end{array}$ & $\begin{array}{l}\text { Standardized } \\
\text { Beta } \\
\text { coefficient }\end{array}$ & $\mathbf{T}$ & Sig. \\
\hline 1 & $\begin{array}{l}\text { Constant } \\
\text { NPLS } \\
\text { DCC }\end{array}$ & $\begin{array}{l}1.319 \\
\mathbf{- 0 . 1 3 7} \\
0.012\end{array}$ & $\begin{array}{l}0.232 \\
\mathbf{0 . 0 3 8} \\
0.011\end{array}$ & $\begin{array}{l}\mathbf{- 0 . 1 5 7} \\
0.0987\end{array}$ & $\begin{array}{l}\mathbf{5 . 6 8 5} \\
-\mathbf{3 . 6 0 5} \\
1.091\end{array}$ & $\begin{array}{l}.000 \\
.000 \\
.311\end{array}$ \\
\hline
\end{tabular}

a. Predictors: (Constant), NPLS, DCC

b. Dependent Variable: ROA

The model summary results in Table 4.12 present the fitness of model used. The coefficient of determination $\left(\mathrm{R}^{2}\right)$ value of 0.366 was obtained meanning that changes in loan lending policies indicators (NPLS and DCC) between the two periods could explain $36.6 \%$ of the variations in the changes in ROA of commercial banks.

The results on the analysis of the variance (ANOVA) indicate that the overall model was statistically significant $(\mathrm{F}=\mathbf{1 3 . 5 0 6}, \mathbf{p = . 0 0 1 7})$ at $5 \%$ level of significance. The results imply that change in the loan lending policies was a good predictor of the changes in the ROA of commercial banks.

Regression coefficient results showed that NPLS had a negative relationship with ROA as indicated by the coefficient -0.137 implying that the decline in the debt collection costs resulted in an increase in the ROA of the banks. On the other hand change in NPLS between the two periods had a positive relationship with ROA implying that if the change was positive, the change in ROA would also be positive. Based on the unstandardized beta coefficients the regression model becomes

$\left(\bar{Y}_{i, t+1}-\bar{Y}_{i t-1}\right)=1.319-0.137\left(\bar{X}_{i a_{i} t+1}-\bar{X}_{i a t-1}\right)+0.012\left(\bar{X}_{i 4 t+1}-\bar{X}_{i 4 t-1}\right)$

The standardized beta coefficients indicate that NPLS had a greater effect size as shown by its larger standardized beta value of 0.038 indicating that a unit increase in debt collection costs results to $3.8 \%$ decline in ROA hence the need for the commercial banks to ensure reduced debt collection cost to ensure increased ROA.

The $\mathrm{t}$-test for the significance of the regression coefficients indicated that the relationship between NPLS and ROA was statistically significant at $5 \%$ level of significance $(t=-3.605, p=.000)$ while the effect of loan term on ROA was not statistically signicant $(\mathrm{t}=1.091, \mathrm{p}=.311)$.

Further to secondary data, primary data was collected on how interest rate regulations affect loan lending policies and financial performance of commercial banks in Kenya. Table 4.13 displays the views of the respondents on the statements. 
Table 4.13: Effect of Interst rate regulation on the relationship between loan lending policies and Financial Performance of commercial banks in Kenya

\begin{tabular}{|c|c|c|c|c|c|c|c|}
\hline Statement & $\begin{array}{l}\text { Not } \\
\text { At all \% }\end{array}$ & $\begin{array}{l}\text { To a } \\
\text { Less } \\
\text { extent \% }\end{array}$ & $\begin{array}{l}\text { To a } \\
\text { Moderate } \\
\text { extent \% }\end{array}$ & $\begin{array}{l}\text { To a } \\
\text { Great } \\
\text { extent } \%\end{array}$ & $\begin{array}{l}\text { To a } \\
\text { Greater } \\
\text { extent \% }\end{array}$ & Mean & $\begin{array}{l}\text { Std. } \\
\text { Dev. }\end{array}$ \\
\hline Interest rate regulation & 2.7 & 19.2 & 23.3 & 37.0 & 17.8 & 3.48 & 1.082 \\
\hline $\begin{array}{l}\text { Increase or decrease of } \\
\text { Interest rates affect } \\
\text { Performance of banks }\end{array}$ & 0.00 & 16.2 & 23.0 & 36.5 & 24.3 & 3.69 & 1.019 \\
\hline $\begin{array}{l}\text { The capping of interest } \\
\text { Rates In } 2016 \text { increased } \\
\text { Demands for Loans and } \\
\text { Increased bank's profits }\end{array}$ & 8.1 & 18.9 & 33.8 & 27.0 & 12.2 & 3.16 & 1.123 \\
\hline $\begin{array}{l}\text { There is a relationship } \\
\text { Between IRR loan portf. } \\
\text { Affect Performance of banks }\end{array}$ & 0.0 & 21.6 & 27.0 & 29.7 & 21.6 & 3.51 & 1.063 \\
\hline $\begin{array}{l}\text { IRR affect loan portf. Mgt } \\
\text { In commercial banks }\end{array}$ & 2.7 & 6.8 & 35.1 & 44.6 & 0.00 & 3.54 & 0.879 \\
\hline $\begin{array}{l}\text { Competition in comm. bank s } \\
\text { lead to differences in IR } \\
\text { Interest rate changes affect }\end{array}$ & 4.1 & 12.2 & 31.1 & 4.5 & 12.2 & 3.45 & 0.995 \\
\hline Performance of banks & 0.0 & 10.8 & 35.1 & 39.2 & 14.9 & 3.43 & 0.876 \\
\hline IRR afect loan portfolio mgt. & 1.4 & 12.2 & 43.8 & 31.9 & 10.8 & 3.49 & 0.895 \\
\hline $\begin{array}{l}\text { Poor loan lending leads } \\
\text { To NPLs }\end{array}$ & 2.7 & 9.5 & 32.4 & 40.5 & 14.9 & 3.55 & 0.752 \\
\hline Average Mean & & & & & & 3.9125 & 0.9649 \\
\hline
\end{tabular}

Source: Research 2020

Table 4.13 shows responses on statements regarding the effect of interest rate regulation on financial performance of commercial banks in Kenya. All the responses on all the statements regarding IRR on financial performance of commercial banks indicated that interest rate regulation and loan lending policies affect financial performance of commercial banks in Kenya. The overall mean score of response regarding NPLs was 3.9125 on a 5 point scale and the overall average standard deviation was 1.9649 . The findings of the current study is in support of a study conducted by Gravin (2010) on the effect of interest rate spread on the performance of Banking Industry in Kenya and the findings indicated that the Central bank regulation, credit risk and macroeconomic environment played a major role in influencing the extent of interest rate spread and hence contributed to the performance of banking industry.

\section{Discussion of Resuts, Findings and conclusion}

5.1 Effect of the Credit risk management and financial performance of commercial banks in Kenya.

The first objective of the study sought to establish the relationship between credit risk management of and financial performance of commercial banks in Kenya.

Ho2.1: Non-performing loans has no significant relationship with Return on Assets of commercial banks in Kenya. Ho2.2: Debt collection costs have no significant relationship with Return on Assets of commercial banks in Kenya.

The findings on secondary data on the relationship between non-performing loans and ROA established a negative and significant relationship at 5\% level of significance. On the relationship between non-performing loans and ROA, the study established a positive relationship which was however not significant at $5 \%$ level of significance.

The findings of the study revealed that, the test for the difference in means of NPLS and DCC before and after interest capping indicated that the difference in the means of NPLS between the two periods was statistically significant $(t=4.500, \mathrm{p}=.000)$ at $5 \%$ level of significance. However, the difference in the mean of DCC between the two periods was not statistically significant $(\mathrm{t}=.317, \mathrm{p}=.751)$ at $5 \%$ level of significance. This indicates that the introduction of interest rate capping caused significant changes in the non-performing loans for the commercial banks but caused no significant difference in debt collection costs.

Hypothesis one $\left(\mathrm{HO}_{1 \mathrm{a}}\right)$ stated that non-performing loans have no significant relationship with ROA of commercial banks. The t-test results $(\mathrm{t}=-6.3390 ; \mathbf{p}=\mathbf{0 . 0 0 0})$ indicate that the relationship between NPLS and ROA is statistically significant. This finding rejected the stated null hypothesis with $95 \%$ confidence and concluded that non-performing loans have a significant effect on the financial performance of commercial banks.

Hypothesis one $\left(\mathrm{HO}_{2 \mathrm{~b}}\right)$ stated that debt collection costs has no significant relationship with ROA of 
commercial banks. The t-test results $(\mathrm{t}=1.02986 ; \mathbf{p}=\mathbf{0 . 0 7 4 1})$ indicate that the relationship between debt collection costs and ROA is not statistically significant. This finding failed to reject the stated null hypothesis with $95 \%$ confidence and concluded that debt collection cost has a non-significant effect on the financial performance of commercial banks.

The findings of the study from primary data revealed that loan portfolio management had a negative influence on return on assets of commercial banks in Kenya. This is supported by the results of the respondents. The results indicated that loan lending policies affects the financial performance of commercial banks as it affects profitability and liquidity.

5.2 Effect of interest rate regulation on the relationship between loan lending policies and financial performance of commercial banks in Kenya.

The second objective sought to determine the effect of interest rate regulation on the relationship between loan lending policies and financial performance of commercial banks in Kenya.

The study data was divided into two periods: the period before the interest rate capping (2013-2015) and the period after the interest rate capping (2017-2018).

The independent samples T-test was used to establish if there was a significant difference in the means of the study variables and pooled regression with differencing was used to establish whether changes in ROA between the two periods was as a result of the changes in the explanatory variables between the two periods.

The results of the study indicated that the mean of ROA before the interest rate capping of 8.8974401 and standard deviation of 1.995 was higher than the mean ROA after the interest rate capping in 2016 (Mean=5.2565423, SD=3.102). The results depicts that the introduction of interest rate capping resulted to a decline in the ROA of the commercial banks in Kenya.

For the credit risk management indicators, the study established a mean Kshs 82.87 million with a standard deviation of 32.273 before interest rate capping and a mean of Kshs 20.43 million with a standard deviation of 38 .165 after interest rate capping for NPLS. This indicated a decline of about $75 \%$ in the non-performing loans hence an implication that the introduction of interest rate capping made it easier for loan lendees to service their loans. For loan debt collection costs, the cost remained the same indicating that there ware no changes in the debt collection costs with the introduction of interest rate regulations.

5.2.1 Effect of Interest rate regulation on the relationship between credit risk management and financial performance of commercial banks in Kenya

$H_{04}: 2$ : Interest rate regulation has no significant effect on the relationship between credit risk management and financial performance of commercial banks in Kenya

To establish the effect of interest rate regulation on the relationship between credit risk managementand financial performance of commercial banks, the study first applied the independent samples t-test to establish whether there was a significant difference in the means of NPLS and DCC for the two periods (before interest rate capping (2013-2015) and that after the interest rate capping (2016-2018)) and then applied pooled OLS regression analysis of the difference in the ROA between the period before interest rate capping (2013-2015) and that after the interest rate capping (2016-2018) on the difference in NPLS and DCC between those two periods. The test for the difference in means of NPLS and DCC before and after interest capping indicate that the difference in the means of NPLS between the two periods was statistically significant $(t=4.500, \mathrm{p}=.000)$ at $5 \%$ level of significance. However, the difference in the mean of DCC between the two periods was not statistically significant $(\mathrm{t}=.317, \mathrm{p}=.751)$ at $5 \%$ level of significance. This indicates that the introduction of interest capping caused significant changes in the non-performing loans for the commercial banks but caused no significant difference on debt collection costs.

\subsection{Conclusion}

The main objective of the study was to determine the effect of interest rate regulation on the relationship between loan lending policies and financial performance of commercial banks in Kenya. Two specific objectives and were derived from the main objective. The first specific objective was to determine the effect of credit risk management on financial performance of commercial banks in Kenya. The second objective was to determine the effect of interest rate regulation on the relationship between loan lending policies and financial performance of commercial banks in Kenya. Panel data from 2013 to 2018 of 43 commercial banks was analysed using multiple linear regression method. From the discussions of the findings above, it was concluded that credit risk management, interest rate regulation and loan lending policies have a significant negative effect on financial performance of commercial banks in Kenya.

The introduction of interest rate regulation let to a significant change in the profitability of the banks with the period after the capping of interest rate registering smaller profitability values than the period before the capping. It can also be concluded that he introduction of interest capping caused significant changes in the non-performing loans and debt collection costs for the commercial banks forcing the banks to diversify their loan portfolios. The 
study also concluded that before and after interest rate capping (2013-2015) and (2016-2018), the loan lending policies variables between the two periods was statistically significant implying that it affected the ROA of commercial banks negatively. The study also concluded that there is a statistical significant relationship between interest rate regulation, loan lending policies and financial performance of commercial banks in Kenya. Based on the above conclusion, the study recommends the following: The study recommended that Commercial banks should not rely majorly on the higher interest rate for their profits, instead they shoul diversify their loan portfolios to enhance profitability. The management of commercial banks is required to ensure that the terms and conditions of granting loans are adhered to before loans are approved. The government should have a fixed interest rate which banks will use as their lending rate because interest rate capping in 2016 brought challenges to the banks until it was repealed in November 2019. Commercial banks should concentrate in lending secured loans with collateral security so that they can be able to recover their money when a customer defaults. Commercial banks should formulate and adopt lending policies that increase the shareholder's value, create customer satisfaction, reduce loan loss default and improve financial performance of commercial banks. Clear credit policies and lending guidelines should be established. Lending policies and guidelines should be approved by senior management and made aware to all staff. This will reduce loss on NPLs and improve the asset quality management which raises bank's expenses and consequently increase profitability. Commercial banks should come up with credit management strategies to caution the banks from the cost of loan risk. The government to come up with policies to limit the amount of loans that banks can lend to the public and the collateral security involved.

\subsection{Suggestions for Further Research}

The study relied on primary and secondary quantitative data obtained by the use of questionnaires and Document Analysis Guide. This restricted the respondent's opinion and therefore for more conclusive information, the same study should be done using other methods of data collection like interviews. Data analysis was based on the opinion of bank managers, operational managers and credit managers of all the 43 commercial banks in Kenya. For more realistic results, it is suggested that further research be done to seek the opinion of customers and other bank workers to establish the effect of interest rate regulation on the relationship between loan portfolio management and financial performance of commercial banks in Kenya. The study used census survey design method of sampling whereby all the 43 commercial banks registered in Kenya were the respondents which made it difficult for the researcher to reach all the respondents to get clear understanding of the effect of interest rate regulation on the relationship between loan portfolio management and financial performance of commercial banks in Kenya. It is suggested that further research be undertaken using stratified random sampling techniques where the population will be grouped into strata for easy of data collection. The study captured the only available secondary data for period 2013 to 2018 which are in CBK records and further study is recommended to incude longer periods for the time series data. Further study is also recommended to be carried out of other deposit taking financial institutions such as microfinance banks, mortgage firms and SACCOS since the banking sector faces many challenges including stiff competition from those institutions.

\section{REFERENCES}

Abadoo A.G. (2015). Determinants of loan default and its effect on financial performance of commercial banks in Ghana. A case study of Fidelit Bank Limited. Unpolished Masters Thesis. University of Ghana

Araka H. (2018). Effect of non-performing loans on financial performance of commercial banks in Kenya, JOUST Masters Thesis, Internationsal Journal of Finance, Accounting and Economics, (IJFAW) ISSN: 2617 - 3135x Vol. 1 (3) 44-51

Bosire (2014). Factors that influence a wide interest rate band in Microfinance Institutions in Kenya. Published MBA Thesis, Ergeton University, Research Journal of Finance and Accunting, ISSN: 2222-1697 (Paper) ISSN 2222-2847 (online) Vol.5 No.7 2014.

Chpkorir M. \& Osiemo K.E. (2014). An Evaluation of Credit Appraisal Techniques Adopted by commercial banks in Kenya in Lending to small and medium sized Enterprises.

Gakure R.U. (2012). Effects of credit Risk Management Techniques on the performance of unsecured Bank loans Employed by Commercial banks in Kenya.

Gravin J. (2010). Factors affecting banking sector interest rate spread in Kenya. Unpublished Masters Thesis, JKUAT

Hurka H. (2017). The impact of credit risk management on profitability of Nordic commercialIN Europe, Published Master Thesis, Lund University

Kimathi (2016). Effect of interest rate spread on performance of commercial banks in Kenya. Published Masters Thesis, UON, Research Journal of finance and accounting, ISSN: 2222-1898 Vol. 4 No.8 2007

Kimando (2013. Determinants of interest rate spread of commercial banks in Kenya. Published MBA Thesis, JKUAT, International Journal of Science and Research (IJSR) ISSN: (ONLINE): 2319-7064.

Kisivuliessendi L. (2013). The Effects of credit risk management on loans portfolio among SACCOS in Kenya 
Unpublished MBA Thesis, University of Nairobi.

Kariuki H.N. (2013). Effect of financial distress on financial performance of commercial Banks in Kenya

Kipyegon and Wandera (2013). Effect of credit information sharing on non-performing loans by the Kenya commercial bank Bungoma, Kenya; University of Nairobi Un published Masters Thesis

Korankye A.A. (2014). Causes and control of loan default or Delinquency in Microfinance Institutions in Ghana Published MBA Thesis, Central University College Accra, Ghana, American International Journal of Contemprorary Research Vol.4 No.12, December, 2014

Maina A.N. (2016). Effect of Lending Practices on financial performance of commercial banks in Kenya A survey of selected banks within Nairobi. Pulished Masters Thesis, International University of Africa, United States.

Matete (2014. Factors affecting pricing of loanable funds by commercial banks in Kenya. Unpublished. Thesis International Journal of Business and Social Science Vol.5 No 7, June (2014)

Munyiri (2010). Lending policies and their effects on performance of commercial banks in Kenya. Published Masters Thesis, University of Nairobi.

Mwiti (2014). Factors affecting credit risk management on loan portfolio of savings and Credit Cooperative societies (SACCOS) in Kenya. Published MBA Thesis, Methodist University. ISSN: 2315-5051, Vol. 3, Issue 7, pp. 789-797.

Ngetich J.C. \& Wanjau K. (2011). The effects of interest rate spread on the level of non-performing assets Acase of commercial banks in Kenya.Unpublished PhD Thesis JKUAT, International Journal of Business and Public Management (ISSN: 2222-6244) Vol.1 (1): 58-65; Mount Kenya University Journal (2011) April.

Nakayiza K.S. (2013). Interest rates and loan portfolio performance in commercial banks. A case of Centenary Bank Entebe Road Branch, Uganda. Unpublished Masters Thesis Lahti University, Uganda 2013

Namutenda K. O. (2017). Effect of lending policies on financial performance of Microfinance Institutions in Kisii County, Kenya. A study of Kenya Women Finance Trust. Published Masters Thesis, University of Nairobi, Kenya

Norhaziah N. \& Mohd N.M. (2012). Factors affecting repayment performance in Microfinance Program in Malaysia. Unpublished PhD Thesis, University of Utara, Malaysia.

Nyaliech C.M. (2017). Factors affecting non-performing loans, a case of KCB Kenya Limited Nairobi Region Published Masters Thesis Catholic University of East Africa

Ochieng J.O. (2014). Effect of Central Bank of Kenya prudential guideline and regulations on the financial performance of commercial banks in Kenya. Unpublished MBA, Thesis, University of Nairobi, Kenya (2014).

Ogilo F. (2012). The impact of credit risk management on financial performance of commercial banks in Kenya Published PhD Thesis, --- DBA Africa Management Review 2012, Vol.3, No122-373

Ongera J.O. (2016). Influence of loan lending policies on financial performance of commercial banks In Kenya A case of selected banks in Kisii Town; Masters Thesis JOOUST. International Journal of Economics and commerce and management Vol. IV issue 112016

Ongore V.O. (2013). Determinants of financial performance of commercial banks in Kenya. International Journal of Economics and Financial issues, Vol.3 No. 1, 2013, pp 237-252, ISSN 2146-4138

Otieno (2013). The effect of lending policies on the level of non-performing loans (NPLS) of commercial banks in Kenya, Published Masters Thesis, University of Nairobi.

Pierre B.J. (2017). Impact of Loan Portfolio Management on performance of commercial banks in Rwanda, A case study of Cogebank (2010-2015). Published Masters Thesis, University of Lay Adventist of Kigali Rwanda

WafulaM.A. (2013). Factors influencing performance of commercial banks in Kenya. Acase of KCB Bungoma, Unpublished PhD Thesis University of Nairobi, Kenya

Were M. \& J. Wambua (2014), Factors driving interest rate spread of commercial Banks, Empirical Evidence from Kenya. A review of development finance Vol. 4, issue 2 (2014), pp.73-82

Wesean A.K.(2014). The impact of interest rate changes on the profitability of four major commercial banks in Parkistan. International Journal of Accounting and Financial Reporting ISSN 2162-3082, Vol.4 No.1 